\title{
POTENTIAL OF PTERIDOPHYTES IN HEAVY METAL PHYTOREMEDIATION
}

\author{
Smruthi G. Prabhu' ${ }^{1}$ G. Srinikethan ${ }^{2}$, Smitha Hegde ${ }^{3}$ \\ ${ }^{I}$ Department of Chemical Engineering, National Institute of Technology Karnataka, Surathkal 575025, Karnataka, \\ India \\ ${ }^{2}$ Department of Chemical Engineering, National Institute of Technology Karnataka, Surathkal 575025, Karnataka, \\ India. \\ ${ }^{3}$ P.G. Department of Biotechnology, St Aloysius College, Mangalore 575003, Karnataka, India
}

\begin{abstract}
Heavy metal pollution of water and soil is becoming a common global environmental problem as a result of mining, industrial, military and agricultural activities. Plants and animals are highly susceptible to heavy metal poisoning at high levels beyond its permissible limits. Conventional processes employed are ineffective on some metals; a few others are extremely expensive and affect the soil fertility. Hence, research has led to the discovery of various plants worldwide, which have been identified to be hyperaccumulators of various heavy metals. The discovery of Pteris vittata, exhibiting normal growth in a chromate copper arsenate made it an interesting research candidate for phytoremediation. Ferns do not play any direct role in the food chain. In addition, they do not have any commercial application. Easy reproduction, rapid growth, wide range habitats and evolutionary traits of heavy metal tolerance should be exploited. Hence, both terrestrial and aquatic ferns should be considered for application in phytoremediation/ biosorption.
\end{abstract}

Keywords: Pteridophytes, Bioaccumulation, Biosorption, Phytoremediation

\section{INTRODUCTION}

Science is the primary reason for the development of the human society. There has been scientific impact on almost all the sectors, today. The sole concern of scientific development is the resulting pollution. Development of machinery has resulted in air, soil, water, noise pollution and much more. Emissions from vehicles have led to air pollution. Soil and water have almost similar sources of pollution. Heavy metal pollution of water and soil is becoming a common global environmental problem. Mining, industrial, military and agricultural activities are the common sources of heavy metal pollution. Industries contribute in causing pollution by the discharge of untreated or partially treated industrial effluent resulting in pollution of soil and water. Industries dealing with metal plating, battery, ceramic and glass manufacturing, paint and pigmentation production are common examples. The excessive use of pesticides for agriculture has an equal role in polluting soil and water. Water pollution can occur through heavy metal run off from soil to water bodies and through the discharge of untreated or partially treated effluents bearing toxic heavy metals from the industries. The leaching of metals results in the groundwater pollution.

There are several conventional methods that can be applied for the heavy metal ion removal. Chemical precipitation, adsorption, membrane technologies, ion exchange and coagulation are some of the methods applied in industries. However, the conventional treatments have certain limitations that impede their application. The disadvantages are applicable to all conventional methods when the concentration of the heavy metals was below $100 \mathrm{mg} / \mathrm{L}$ (Tomko et al. 2006). Limitations of the conventional treatment that have inhibited their wide application are high chemical consumption, high cost, sludge formation and its disposal. Thus, the industries have opted for the discharge of partially treated or untreated effluent into water bodies.

Heavy metals even at low concentrations can have disastrous effects on animal and environmental health due to their persistence and accumulation tendency. The permissible limits for industrial effluent discharge bearing heavy metals have to be followed as per the standards of Indian pollution Control Board and WHO. If the intake is beyond the permissible limits it causes symptoms as simple as irritation of eyes, mouth, nose and could be as hazardous as causing cancer of various forms. Therefore, efficient removal of heavy metals from the primary source is of extreme importance.

An intention to replace the conventional methods has led to the application of various plants identified to be hyperaccumulators of various heavy metals in the heavy metal polluted land. Low-cost investment and ecofriendliness of phytoremediation have resulted in its demand for the application. Phytoremediation is defined as the use of plants to remove the toxic substances from the environment (Baldwin and Butcher 2006, Natarajan et al. 2010). Active removal or uptake of metals by active living cells is called bioaccumulation, should not be confused with biosorption (Malik 1999). Biosorption is yet another technique that is gaining attention due to its possible application in heavy 
metal removal from industrial effluents in-situ. Fomina and Gadd (2014) defined Biosorption as the passive uptake of solutes by inactivated organism. In this review, we have included the heavy metal removal using pteridophytes via both phytoremediation and biosorption.

\section{Application of Pteridophytes in Phytoremediation}

\section{Background}

Pteridophytes are the most primitive, well- developed vascular plants to habitat on land. They are able to strive on land or water where other plants may not be able to grow or survive. Pteridophytes are well- evolved and have the ability to withstand various abiotic stress factors including high concentrations of heavy metals. Pteridophytes or ferns have a limited role in food for animals and humans (Sajeev et al. 2013), making those suitable candidates for Phytoremediation and biosorption studies.

\section{Advantages of using ferns for Phytoremediation and Biosorption}

In 2001, scientists had reported the growth of Pteris vittata L., Chinese Brake fern in a chromate copper arsenate contaminated site in Central Florida. As ferns have no role to play in the food chain they have received much attention in heavy metal removal. Ferns are usually not the desired feed when compared to angiosperms. Hence, ferns are considered weeds as they are not extensively utilized as a source of vegetation by animals or humans. Moreover, some species of ferns (Paesia scaberula) are generally destroyed by humans due to their invasive nature affecting other vegetation. Likewise, Nephrolepis cordifolia (L.) C. Presl (Fishbone fern) has been reported to be an invasive weed that prevents the regeneration of the native plants. Nephrolepis exaltata (L.) Schott (Sword fern) has been reported to be a serious problem in cultivating Phalaenopsis orchids (Ko et al. 2004). Thus, the ferns can be exclusively applied in heavy metal removal over other reported hyperaccumulators. Presently, there have been several field trials that employ ferns in phytoremediation of heavy metals. Among them Pityrogramma calomelanos (L.) Link, Pteris vittata L. and Azolla spp. have been reported, in literature, to be successfully applied. The family that dominates with several hyperaccumulators is the Pteridaceae family which include Pteris vittata L., $P$. cretica, $P$. longifolia and $P$. umbrosa. Hyperaccumulating ferns are viable even at high metal concentrations during the accumulation period. These characteristics of ferns may play a critical role in field and industrial applications. Last but not the least, the recycle of ferns and byproducts for heavy metal removal reduces the wastes in an environmentally friendly manner. Hence, it agrees well with the concepts of effective, innovative and sustainable waste management.

\section{Fern Species Applied in Phytoremediation}

Aquatic and terrestrial fern forms have the ability to remediate heavy metals. For clarity, all the results will be expressed in heavy metal removal efficiency rather than in percentage. Azolla spp. due to their abundant availability is the most studied aquatic fern or macrophyte in heavy metal removal from polluted water bodies. Sood et al. (2011) in their study have reported Azolla spp. to be a potent aquatic fern for phytoremediation for the following reasons: fast growth rate, nitrogen fixing ability and easy disposal. Azolla caroliniana Willd. has the highest heavy metal accumulating capacity of $963 \mathrm{mg} / \mathrm{dm}^{3}$ for chromium and $578 \mathrm{mg} / \mathrm{dm}^{3}$ for mercury (Bennicelli et al. 2003). Other Azolla spp. reported in heavy metal accumulation are A. pinnata, A. microphylla and $A$. imbricata (Sood et al. 2011)

Dhir (2009) in his study has put forward the phytoremediation capacity of another aquatic fern, Salvinia spp. The heavy metal uptake capacity of Salvinia is equally efficient as when used in its non- living form. Begu and Harikrishna (2010) have reported the efficient phytoremediation at lower concentrations of heavy metals like iron, nickel and copper. Salvinia spp. When compared with other hydrophytes like Hydrilla vercillata Casp. and Elodea canadensis Rich, Salvinia spp. showed the better removal of heavy metal for a longer period. But the aquatic plants showed morphological changes as signs of toxicity post 5 days. Unlike the findings of Begu and HariKrishna (2010), Salvinia molesta was found to healthily grow in the presence of copper (Ranjitha et al. 2016). But the initial copper concentration was found $2 \mathrm{mg} / \mathrm{L}$ in contrast with 5 $\mathrm{mg} / \mathrm{L}$ used by Begu and Harikrishna (2010). Salvinia sp. in comparison to other water weeds shows better copper accumulation over other heavy metals like lead, arsenic and cadmium (Sukumaran 2013). Other studies on heavy metal accumulation using Salvinia spp. has been shown in Table 1.

Very high concentrations of heavy metals could be toxic. Azolla filiculoides showed relatively good uptake of $\mathrm{Pb}$ and $\mathrm{Zn}$. The toxic effect was determined by studying the metabolism of soluble sugar, reducing sugar and a nonreducing sugar, which at higher metal concentration were not completely reduced (Sheel et al. 2013). Similar observations were made in A. caroliniana Willd, showed higher metal accumulation in spite of inhibition of growth by $20-31 \%$. This proved that $A$. caroliniana is the only aquatic fern with such high metal accumulating potential when compared with any other hydrophytes. It is not right in comparing Salvinia spp. with Azolla spp. to establish which has the better potential in phytoremediation of heavy metals; as the parameters used varies from one study to another. Salvinia possesses an inherent capacity to accumulate $\mathrm{Cr}$, $\mathrm{Fe}, \mathrm{Ni}, \mathrm{Cu}, \mathrm{Pb}$ and $\mathrm{Cd}$ in the range of $6-9 \mathrm{mg} / \mathrm{g}$ dry weight, while $\mathrm{Co}, \mathrm{Zn}$ and $\mathrm{Mn}$ in the range of $4 \mathrm{mg} / \mathrm{g}$ dry weight (Dhir et al. 2011). But it can be observed from studies that Azolla spp. though are physiologically affected by the toxic heavy metals their ability to accumulate heavy metals was not drastically affected. A study by Dhir et al. (2011) reported the alteration in photosynthetic potential in the presence of heavy metals without affecting the photochemical reactions and photophosphorylation potential in Salvinia, widening its scope for application in phytoremediation. Hence, to have a concrete proof as to which aquatic fern is a relatively better accumulator, comparative study with same parameters has to be conducted. 
Table 1 Heavy metal accumulation by different Salvinia spp

\begin{tabular}{|c|c|c|}
\hline $\begin{array}{l}\text { Salvinia } \\
\text { spp. }\end{array}$ & $\begin{array}{l}\text { Heavy } \\
\text { metal }\end{array}$ & Reference \\
\hline $\begin{array}{l}\text { Salvinia } \\
\text { natans }\end{array}$ & $\begin{array}{l}\text { Boron- } \\
0.06 \\
\mathrm{mg} / \mathrm{g} \\
\text { Dry Wt. }\end{array}$ & $\begin{array}{l}\text { Holtra et } \\
\text { al. } 2010\end{array}$ \\
\hline $\begin{array}{l}\text { Salvinia } \\
\text { molesta }\end{array}$ & $\begin{array}{l}\mathrm{Cu}, \quad \mathrm{Fe} \\
\text { and } \mathrm{Pb}\end{array}$ & $\begin{array}{l}\text { Preetha } \\
\text { and } \\
\text { Kaladevi } \\
2014\end{array}$ \\
\hline $\begin{array}{l}\text { Salvinia } \\
\text { minima } \\
\text { Baker }\end{array}$ & $\begin{array}{l}\mathrm{Ni}-16.3 \\
\mathrm{mg} / \mathrm{g} \\
\text { Dry Wt. }\end{array}$ & $\begin{array}{l}\text { Fuentes et } \\
\text { al. } 2014\end{array}$ \\
\hline $\begin{array}{l}\text { S. minima } \\
\text { S. auriculata } \\
\text { S. herzogii } \\
\text { S. } \\
\text { rotundifolia } \\
\text { S. natans }\end{array}$ & $\begin{array}{l}\mathrm{As}, \quad \mathrm{Pb}, \\
\mathrm{Cd}, \mathrm{Cr} \\
\mathrm{Hg} \\
\mathrm{Cd}, \mathrm{Cr} \\
\mathrm{Pb} \\
\begin{array}{l}\mathrm{Ni}, \quad \mathrm{As} \\
\mathrm{Cu}\end{array}\end{array}$ & Dhir 2009 \\
\hline
\end{tabular}

Several terrestrial ferns have been studied for its heavy metal accumulating potential. Arsenic is that one metal that has been extensively studied. Zhao et al. (2002) has noted Pteris vittata L. (Ma et al. 2001) to be the first and repeatedly reported fern as an arsenic hyperaccumulator by accumulating 14,500 mg/kg of As (Jadia and Fulekar 2008).
Recently, several other ferns of pteridales order were identified to be arsenic hyperaccumulators. Pityrogramma calomelanos, Pteris cretica, Pteris longifolia and Pteris umbrosa are few of the ferns that are heard of (Wang 2003). Several ferns are yet to be screened for their heavy metal hyperaccumulating ability. Genetic diversity of Pteris vittata L. makes them potential hyperaccumulators of heavy metals (Pal and Chunari 2015). P. cretica L., P. longifolia L. and P. umbrosa $\mathrm{R}$. Br. are the few of the many hyperaccumulators belonging to Pteris genus. Baldwin and Butcher (2006) in their study using the hydroponic system successfully characterized the uptake and accumulation of As to be higher in leaves and stem, than roots. Natarajan et al. (2011) in their study have observed the arsenic removal be better in healthy ferns and growing fronds. Thus there is an utmost need to harvest the fronds carefully such that the growth of the ferns is continuous and not affected. The arsenic accumulation was found to be in amounts equal as in fronds. Pteris are accumulators as they biodegrade the contaminants into its inert form (Tangahu et al. 2011). It has been found that the heavy metal uptake improved when the fern, $P$. vittata was associated with Arbuscular Mycorrhizal (AM) fungus. To their surprise, there was little or no effect of arsenic application on AM fungus (Liu et al. 2004). Thus it was an approach that could enhance the heavy metal accumulation in fern.

Francesconi et al. (2001) have reported the arsenic accumulation in Pityrogramma calamelanos to occur in fronds (up to $8350 \mu \mathrm{g}$ As /g dry mass) and in rhizoids at a lower concentration of 88- $350 \mu \mathrm{g}$ As /g dry mass. Pteridophytes that can be applied in phytoremediation of heavy metals are tabulated below (Table 2).

Table 2 Application of pteridophytes in phytoremediation (Drăghiceanu et al. 2014; Kachenko et al. 2007)

\begin{tabular}{|c|c|c|c|c|}
\hline Pteridophyte & Known application & $\begin{array}{l}\text { Heavy } \\
\text { metal }\end{array}$ & $\begin{array}{l}\text { Heavy metal accumulated } \\
\text { (dry weight basis) }\end{array}$ & $\begin{array}{l}\text { Note on } \\
\text { heavy } \\
\text { metal } \\
\text { sensitivity }\end{array}$ \\
\hline $\begin{array}{l}\text { Asplenium } \\
\text { australasicum- } \\
\text { leaves }\end{array}$ & Phytoremediation & As & $\begin{array}{l}1,240 \mu \mathrm{g} \text { As/g dry weight } \\
\text { (DW) }\end{array}$ & $\begin{array}{l}\text { Symptoms } \\
\text { of toxicity } \\
\text { observed- } \\
\text { not used } \\
\text { above } 50 \\
\mathrm{mg} / \mathrm{L}\end{array}$ \\
\hline $\begin{array}{l}\text { A.bulbiferum - } \\
\text { leaves }\end{array}$ & Phytoaccumulation & As & $\begin{array}{l}2,630 \mu \mathrm{g} \text { As/g dry weight } \\
\text { (DW) }\end{array}$ & $\begin{array}{l}\text { Symptoms } \\
\text { of toxicity } \\
\text { observed- } \\
\text { not used } \\
\text { above } 50 \\
\mathrm{mg} / \mathrm{L}\end{array}$ \\
\hline $\begin{array}{l}\text { Adiantum } \\
\text { capillus- } \\
\text { veneris- } \\
\text { and leaves }\end{array}$ & $\begin{array}{l}\text { Phytostabilization- } \\
\text { cannot be applied if } \\
\text { soil is heavily } \\
\text { contaminated. }\end{array}$ & As & $\begin{array}{l}1,190 \text { and } 370 \mu \mathrm{g} \mathrm{As} / \mathrm{g} \text { dry } \\
\text { weight (DW) }\end{array}$ & NA \\
\hline $\begin{array}{l}\text { Pteris cretica, } \\
\text { Pterisumbrosa- } \\
\text { leaves and }\end{array}$ & Phytoaccumulation & As & $\begin{array}{l}3,090 \text { and } 760 \mu \mathrm{g} \text { As/g dry } \\
\text { weight (DW) }\end{array}$ & $\begin{array}{l}\text { High } \\
\text { tolerance }\end{array}$ \\
\hline
\end{tabular}




\begin{tabular}{|c|c|c|c|c|}
\hline rhizoids & & & & \\
\hline $\begin{array}{ll}\text { Pteris } & \text { cretica- } \\
\text { leaves } & \\
\end{array}$ & Phytoaccumulation & $\mathrm{Sb}$ & $1516.5 \mathrm{mg} / \mathrm{kg}$ & $\begin{array}{l}\text { High } \\
\text { tolerance }\end{array}$ \\
\hline $\begin{array}{l}\text { Dennstaedtia } \\
\text { davallioides }\end{array}$ & \multirow{3}{*}{ Phytoaccumulation } & $\begin{array}{l}\mathrm{Cd} \\
\mathrm{Cu}\end{array}$ & $\begin{array}{l}386 \\
32 \mu \mathrm{g} \mathrm{g}-1 \text { dry weight (DW) }\end{array}$ & \multirow{3}{*}{$\begin{array}{l}\text { Good } \\
\text { tolerance }\end{array}$} \\
\hline Pellaea falcate- & & $\begin{array}{l}\mathrm{Cd} \\
\mathrm{Pb} \\
\mathrm{Ni} \\
\mathrm{Cr} \\
\mathrm{Zn}\end{array}$ & $\begin{array}{l}87.9 \\
62 \\
68 \\
33 \\
107 \mu \mathrm{g} \mathrm{g}-1 \text { dry weight }(\mathrm{DW})\end{array}$ & \\
\hline $\begin{array}{l}\text { Nephrolepis } \\
\text { cordifolia }\end{array}$ & & $\begin{array}{l}\mathrm{Cd} \\
\mathrm{Cr}\end{array}$ & 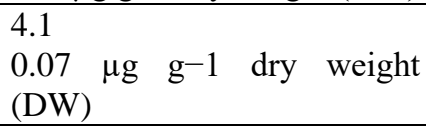 & \\
\hline $\begin{array}{l}\text { Blechnum } \\
\text { cartilagineum }\end{array}$ & & $\begin{array}{l}\mathrm{Ni} \\
\mathrm{Zn}\end{array}$ & $\begin{array}{l}121 \\
202 \mu \mathrm{g} \mathrm{g}-1 \text { dry weight (DW) }\end{array}$ & \\
\hline
\end{tabular}

The experimental conditions in literature were varied. Therefore, identifying the best among the few of the abovementioned ferns for the purpose of phytoremediation would not be justified.

\section{MECHANISM OF METAL UPTAKE}

Plants in general either act as accumulators or excluders. Excluders restrict the uptake of the contaminant into their biomass. Accumulators can resist the high concentration of the contaminants accumulated in their aerial tissues. Accumulators have the ability to biotransform the contaminant into an inert form in its tissues. Plants have evolved very efficient mechanisms for the uptake and transport of micronutrients. These mechanisms are involved in the uptake of toxic metals, as their chemical properties simulate those of essential elements. But, plants do not accumulate any micronutrient beyond its metabolic need. Thus, the uptake of toxic metals is minimal (Tangahu et al. 2011). Hyperaccumulators are the living exceptions. Hyperaccumulators can accumulate micronutrients or toxic metals in thousands of ppm. Hence, they can be successively applied in phytoremediation.

Transporter proteins and intracellular high- affinity binding sites mediate the heavy metal uptake across the plasma membrane. Classes of proteins that are concerned with heavy metal uptake are heavy metal ATPases, resistanceassociated macrophage protein (Nramp), cation diffusion facilitator (CDF) and ZIP family. The compartmentalization of heavy metals occurs with an intention of reducing its toxicity. ATPases present in the plasma membrane may be responsible for the sequestration of toxic heavy metals in vacuoles, Golgi or endoplasmic reticulum (Yang et al. 2005). Accumulation of arsenic takes place in the cytosol, cadmium and zinc in leaf vacuoles, antimony in the cell wall, cytoplasmic organelle and cytosol (Srivastava et al. 2005). The uptake of As occurs via phosphate cycle and $\mathrm{Zn}$ via transporters, Zinc-regulated Transporter/ Iron-regulated Transporter (ZIP) proteins in Pteris vittata L. Specific metal uptake could be affected by the concentration of other metals (Feng et al.2010) and over-expression of the transporters (McGrath and Zhao 2003) leading to its hyperaccumulation.

Early terrestrial plants evolved around subaerial hot springs, during which the levels of As were relatively higher. Consequently, the plants had to cope with high As levels in their environment, with this capability conferred on modern plants. Pteris species, in general, have the ability to accumulate As at high concentrations. It has been predicted that the trait developed for evolutionary benefits (Zhao et al. 2002). The tolerance trait towards arsenic could be due to the conversion of arsenate to a less toxic form arsenite. In addition, at low root arsenic concentrations and high phosphorous: arsenic ratio exhibits higher arsenic affinity. Conversion of arsenate to arsenite occurs in the roots by the enzyme arsenate reductase (Duan et al. 2005). On the other hand, Luongo and Ma (2005) claim the conversion to occur in the frond. The exact location of detoxification is yet to be ascertained. But, with high arsenic mobility, $90 \%$ of the arsenic (toxic or detoxicated form) taken up from the soil was transported to the fronds. Other enzymes like superoxide dismutase, catalase and ascorbate peroxidase, in higher concentrations reveal signs of arsenic detoxification (Srivastava et al. 2005).

Morphological and biochemical changes promote hyperaccumulation. Findings of (Bondada and Ma 2003) state that As presence may have stimulatory effects on the root hair development in Pteris vittata when compared to the presence of $\mathrm{Cd}$. This increases the surface area and the number of transporters required for arsenic uptake. In Pteris spp., exposure of fronds to $\mathrm{Cd}$ led to its absorption at the tip of the frond. Over a period of time, the uptake was uniform throughout due to increased proline concentration upon exposure to $\mathrm{Cd}$ that spread evenly through the entire leaf. Proteins are important ligand atoms and play an important role in metal sorption (Sharma and Sachdeva 2015). Cadmium ion acts as an abiotic stress. Increased protein level can be related to the increased enzymatic antioxidants produced to recover from the oxidative stress. The production rate depends on the tolerance of the plant towards the heavy metals (Sajeev et al. 2013). 
Excluders restrict the availability of heavy metals by rhizofiltration. Athyrium yokoscence was studied for removal of $\mathrm{Cu}, \mathrm{Zn}$ and $\mathrm{Cd}$. Copper tolerance of the fern was due to the inhibition of the transport of $\mathrm{Cu}$ from the root cell wall to its cytoplasm. On the other hand, high zinc and cadmium concentrations were found in the cytoplasm. Cellulose and lignin found in the cell walls play a major role in the adsorption of the $\mathrm{Cu}$ ion (Nishizono et al. 1987). Thus, the fern can be applied for adsorption and recovery of copper from the biomass. The exact mechanism of metal uptake, tolerance and its detoxification is not studied, reported or completely understood in the recorded fern hyperaccumulators. This warrants further in-depth study that would promote formulating effective strategies to develop genetically engineered plants that can accumulate specific metals.

Limitations associated with Phytoremediation could cutback its application in-situ. Growing time or long application duration, climate, root depth, soil chemistry and level of contamination are the major limitations (Salido et al. 2010).

\section{BIOSORPTION OF HEAVY METALS USING FERN BIOMASS}

The above limitations of Phytoremediation can be prevented in biosorption. Literature available on biosorption using ferns are predominantly on tree fern and aquatic fern, Azolla. Tree ferns are available both naturally and commercially in Taiwan. Hence, they are agricultural waste materials (Ho 2003). Azolla can colonize on the aquatic surface rapidly. Controlling its rapid reproduction rate led to the development of Azolla based biosorbents. Azolla filiculoides is one of the hyperaccumulators of heavy metals (Asbchin et al. 2012). Non-living Azolla filiculoides (collected from rice fields) was activated using $\mathrm{MgCl}_{2}$ and $\mathrm{H}_{2} \mathrm{O}_{2}$ and the uptake of $\mathrm{Pb}^{2+}, \mathrm{Zn}^{2+}, \mathrm{Cu}^{2+}$ and $\mathrm{Cd}^{2+}$ were studied. Conversion of the hydroxyl group to carboxyl groups by oxidation increased the metal uptake (Ganji et al. 2005). Zhao and Duncan. (1997) reported the $\mathrm{Ni}^{2+}$ removing efficiency both in batch and column operation by Azolla filiculoides. Moreover, Zhao et al. (1999) successfully proved the efficiency of dried Azolla filiculoides at pH 6.0 in the batch study and $\mathrm{pH} 6.2$ in column operation with $60 \%$ breakthrough. Both $\mathrm{Ni}^{2+}$ and $\mathrm{Zn}^{2+}$ could be desorbed almost completely using $0.2 \mathrm{~N} \mathrm{H}_{2} \mathrm{SO}_{4}$ or $\mathrm{HCl}$.

Azolla filiculoides subjected to pre-treatment, semi- intact, activated and inactivated forms showed that activated form exhibited the best biosorption. Mentioned below in the table is the absorption capacity $(\mathrm{mg} / \mathrm{g}$ ) of the activated form of Azolla (Khosravi et al. 2005). Fogarty et al. (1999) did a comparative study between immobilized, mill- sieved and untreated Azolla. Results obtained reveal the effectiveness of epichlorohydrin immobilized biomass over the untreated Azolla. Mill- sieved biomass was found to be the best form. Other papers that have studied Azolla filiculoides as a potential biosorbent of heavy metals are by Mashkani et al. (2009), Rakhshaee et al. (2005) (Table 3). Shoel et al. (2001) have noted the importance of pectin in sorption of $\mathrm{Sr}^{2+}$. As biosorption is $\mathrm{pH}$ dependent phenomena there is lower biosorption at lower $\mathrm{pH}$ due to the competition between the metal ion and $\mathrm{H}^{+}$. It has been found that pectin composition also plays a major role in biosorption. When the biomass was treated with Pectinase and methylated the biosorption was reduced drastically.

Valuable heavy metals like gold have also been recovered from the synthetic solutions. A dilute solution of gold, similar to the concentration present usually in effluents was prepared and studied with. Further studies by Antunes et al. (2000) for direct biosorption and recovery of gold from waste water are being carried out.

Tree fern has been extensively studied in its adsorption capacity of various metals. Predominantly an agricultural waste, Tree ferns have been studied for its biosorption of various metal ions. The uptake of $\mathrm{Cu}$ ion was found to be spontaneous and endothermic in nature (Ho 2003). $\mathrm{pH}$ studies were conducted to determine its effect on biosorption. It was found to be a clear case of ion exchange sorption. $\mathrm{pH} 4.9$ was the optimum $\mathrm{pH}$ for the sorption of $\mathrm{Pb}$ (Ho 2004). Tree fern has a negative surface charge, as a result, it has the capacity only to bind to the cations and not anions. Hence heavy metal ions like arsenate cannot be adsorbed (Ho 2003).

Table 3 Fern based biosorbents used in heavy metal uptake

\begin{tabular}{|c|c|c|c|}
\hline Biomass & Metals/ complex & $\begin{array}{l}\text { Adsorption capacity } \\
(\mathrm{mg} / \mathrm{g})\end{array}$ & Reference \\
\hline \multicolumn{4}{|l|}{ Azolla filiculoides } \\
\hline \multirow{4}{*}{$\begin{array}{l}\text { Azolla filiculoides (dry) } \\
\mathrm{H}_{2} \mathrm{O} \text { or } \mathrm{Mgcl}_{2} \text { treated }\end{array}$} & $\mathrm{Pb}^{2+}$ & 228 & \multirow[t]{4}{*}{ Ganji et al. 2005} \\
\hline & $\mathrm{Zn}^{2+}$ & 86 & \\
\hline & $\mathrm{Cu}^{2+}$ & 33 & \\
\hline & $\mathrm{Cd}^{2+}$ & 34 & \\
\hline \multirow[t]{4}{*}{ Azolla filiculoides (dry) } & $\mathrm{Ni}^{2+}$ & 45.193 & \multirow[t]{2}{*}{ Asbchin et al. 2012} \\
\hline & $\mathrm{Cu}^{2+}$ & 34.314 & \\
\hline & $\mathrm{Zn}^{2+}$ & 45.2 & Zhao et al. 1999 \\
\hline & $\mathrm{Ni}^{2+}$ & 43.4 & Zhao and Duncan 1997 \\
\hline
\end{tabular}




\begin{tabular}{|c|c|c|c|}
\hline \multirow[t]{2}{*}{ Azolla filiculoides (Activated) } & $\mathrm{Pb}^{2+}$ & 271 & \multirow[t]{4}{*}{ Khosravi et al. 2005} \\
\hline & $\mathrm{Cd}^{2+}$ & 111 & \\
\hline & $\mathrm{Ni}^{2+}$ & 71 & \\
\hline & $\mathrm{Zn}^{2+}$ & 60 & \\
\hline $\begin{array}{lll}\begin{array}{l}\text { Azolla } \\
\text { sieved) }\end{array} & \text { filiculoides } & \text { (Mill- } \\
\end{array}$ & \multirow[t]{2}{*}{$\mathrm{Cu}^{2+}$} & 23.07 & \multirow[t]{2}{*}{ Fogarty et al. (1999) } \\
\hline $\begin{array}{ll}\begin{array}{l}\text { Azolla } \\
\text { (immobilized) }\end{array} & \text { filiculoides } \\
\end{array}$ & & 20.33 & \\
\hline Azolla filiculoides & $\mathrm{Au}(\mathrm{III})$ & $2-10$ & Antunes et al. 2000 \\
\hline \multicolumn{4}{|l|}{ Tree fern } \\
\hline \multirow[t]{4}{*}{ Tree fern } & $\mathrm{Pb}^{2+}$ & 40 & Ho et al. 2003 \\
\hline & $\mathrm{Cu}^{2+}$ & 11.7 & Ho 2003 \\
\hline & $\mathrm{Cd}^{2+}$ & 16.3 & Ho and Wang 2003 \\
\hline & $\mathrm{Hg}^{2+}$ & 26.5 & Ho and Wang 2007 \\
\hline Bracken fern & $\mathrm{Cr}(\mathrm{VI})$ & 83.19 & García et al. 2010 \\
\hline
\end{tabular}

Bracken fern has been reported to be an efficient biosorbent of $\mathrm{Cr}(\mathrm{VI})$. $\mathrm{Cr}(\mathrm{VI})$ was initially reduced to $\mathrm{Cr}(\mathrm{III})$, then sorbed onto the biomass which occurred at $\mathrm{pH} 4$. Column studies have proved the reduction to be effective at $\mathrm{pH} 2$ and adsorption at $\mathrm{pH}$ 5. Available literature on biosorption of heavy metals using a dead form of fern hyperaccumulators is found to be limited.

\section{BIOSORPTION MECHANISM OF HEAVY METALS BY FERNS}

Biosorption is determined by complex structural component, functional groups present in the biomass interact with the metal species to varying degrees. In addition, a number of physicochemical properties determine the biosorption performance of the biosorbent.

\subsection{Functional Groups Present in Fern Biomass}

Asbchin et al. (2011) reported the functional groups, surface hydroxyl groups from overlapped $\mathrm{O}-\mathrm{H}$ and $\mathrm{N}-\mathrm{H}$ stretching vibrations, methylene groups from $\mathrm{C}-\mathrm{H}$ symmetric stretch, methyl groups, carboxylate groups from $\mathrm{C}=\mathrm{O}$ stretching vibration and $\mathrm{C}-\mathrm{O}$ stretching vibrations of ketones, aldehydes, lactone. A slight shift in the wavenumbers corresponding to the functional groups on Azolla filiculoides was observed post biosorption. Hence, participate in the sorption of Nickel and copper ions. Carboxyl and phosphate groups present on cell wall might be responsible for the initial binding of metal ions to the biosorbent as noted by Ganji et al. (2005). Activation of the biosorbent, Azolla filiculoides with $\mathrm{MgCl}_{2}$ and $\mathrm{H}_{2} \mathrm{O}_{2}$ showed the sorption to be improved as $\mathrm{Mg}$ ions acted like the exchange ion, hence, replacing the lost ions like $\mathrm{Mg}^{2+}, \mathrm{Ca}^{2+}, \mathrm{Na}^{+}$and $\mathrm{K}^{+}$during washing of the biomass at neutral $\mathrm{pH}$. Adding on to the aforementioned, the plant cell wall is composed of high amounts of pectin. Polygalacturonic acid chains with a glycosidic bond $(1 \rightarrow 4)$ tend to interact with $\mathrm{Ca}$ and $\mathrm{Mg}$ ions to form a three-dimensional polymer. Use of treating agent like $\mathrm{CaCl}_{2}$ and previously mentioned $\mathrm{MgCl}_{2}$, form ($\mathrm{COO})_{2} \mathrm{Ca}$ by exchange of one $\mathrm{Ca}$ ions with two protons of neighboring carboxyl groups. This increases the ion exchangeability or heavy metal uptake by Azolla (Khosravi et al. 2005). The role of carboxyl group has been justified by Khosravi et al. (2005) in their study. Azolla upon inactivation by acid treatment by $\mathrm{HCl}$, three-dimensional pectin structures, responsible for higher metal uptake was hydrolysed. Similarly, the effect of methanol in inactivation dominated compared to ethanol. Methylation of the carboxyl group was more rapid and complete. Use of $\mathrm{FeCl}_{2}$, $\mathrm{SrCl}_{2}, \mathrm{BaCl}_{2}$ and $\mathrm{AlCl}_{3}$ exhibited higher affinity to the cell wall sites in Azolla relative to $\mathrm{Pb}^{2+}, \mathrm{Cd}^{2+}, \mathrm{Ni}^{2+}$ and $\mathrm{Zn}^{2+}$.

Mashkani and Ghazvini (2009) studied upon chemically modified Azolla filiculoides in the uptake of $\mathrm{Cs}$ and Sr. Study reported hydrogen peroxide- $\mathrm{MgCl}_{2}$ treated biomass to be an efficient biosorbent. Carboxylic acid, amines, phosphate and sulfonates were the functional groups responsible for metal sorption. Micro-proton induced X-ray emission studies showed the mechanism behind the uptake of $\mathrm{Cs}$ and $\mathrm{Sr}$ in Azolla to be bioaccumulation and not biosorption.

In tree fern chemical sorption of the heavy metals takes place. The polar functional groups of lignin-like alcohols, aldehydes, ketones, acids phenolic hydroxides and ethers act as the chemical bonding agents (Ho 2003). In Bracken fern, heavy metal uptake involves mainly two steps. Initially, it involves the reduction of $\mathrm{Cr}$ (VI) to $\mathrm{Cr}$ (III) followed by its adsorption (García et al. 2010).

\subsection{Physico-Chemical Factors Affecting Biosorption}

\section{Mechanism}

Fomina and Gadd (2014) have expressed the role of physicochemical factors in determining the performance of the biosorbent. $\mathrm{pH}$ has a major effect on the biosorption rate. For the sorption of cations, $\mathrm{Cu}(\mathrm{II})$ and $\mathrm{Ni}(\mathrm{II})$ Asbchin et al. (2012) inferred that lower $\mathrm{pH}$ resulted in competition between the metal ions and protons for the binding sites resulting in lower biosorption. On the other hand, higher $\mathrm{pH}$ led to the precipitation of metal ions. Vijayaraghavan and Yun (2008) have reported the use of higher $\mathrm{pH}$ range in the 
sorption of cations. Similar results were obtained by Zhao and Duncan (1997) for the Ni (II) uptake and optimum uptake by Azolla filiculoides were observed at $\mathrm{pH} 6.5$. Precipitation of Ni (II) was not observed till $\mathrm{pH} 7.0$ as the natural $\mathrm{pH}$ of the $\mathrm{NiCl}_{2}$ solution was 7.3. $\mathrm{pH}$ closer to the neutral range, 5.5, 6, 5.5, 6.7, influenced the uptake of heavy metal ions, $\mathrm{Pb}^{2+}, \mathrm{Cd}^{2+}, \mathrm{Cu}^{2+}$ and $\mathrm{Zn}^{2+}$ by Azolla filiculoides (Ganji et al. 2005). But maximum Cs and Sr sorption were achieved at $\mathrm{pH} 8$ and 9 due to the negative surface charge of the biosorbent. Antunes et al. (2000) observed the complete sorption of gold (III) at low pH of 2. Gold (III) being an anion was completely adsorbed on the positively charged biosorbent due to proton distribution at low $\mathrm{pH}$.

Mashkani and Ghazvini (2009) in their study obtained higher sorption at larger particle size which goes against the principle of surface area. They justify their results by clarifying the fact that architecture of the biosorbent might play a bigger role than its size. For an application, having a larger particle size with high absorptivity is favorable. In addition, other parameters like temperature, metal ion (pollutant) concentration, and biosorbent dosage and agitation rate influence the metal uptake.

\section{DISPOSAL OF CONTAMINATED BIOMASS}

Disposal of metal-laden biomass should be done responsibly. Incineration of this biomass could result in the release of toxic forms of metals. The subjection of the biomass to landfills is not a good option either. If the conditions are not favorable, heavy metal leaching into the groundwater could occur. Disposal of the arsenic-laden fern directly into the sea has been suggested. The rationale behind this approach of disposal is the ability of the marine unicellular algae to biotransform inorganic arsenic to nontoxic forms by natural process. Regardless, further investigations are required to have a clear idea on safe disposal Francesconi et al. (2001). However, if the rate of biotransformation is slow, the immediate toxic effects of arsenic on the aquatic forms might be evident. This could lead to widespread heavy metal poisoning as a result of biomagnification. Further investigation on proper disposal of hazardous biomass is necessary.

\section{CONCLUSION}

Pteridophytes have the ability to grow both in extreme habitats as well as extreme climatic conditions. When other plants fail to cope up with booming urbanization, pteridophytes are resiliently growing on concrete structures. Easy availability, resistance and rapid reproduction are the characteristics that promote their application as heavy metal accumulators and adsorbers. One must be very cautious in consuming ferns as food and medicine as they could have high heavy metal concentration beyond the safe permissible limit. Instead, their application as accumulators should be supported. Ferns have excess 'above ground' biomass as compared to root. The root system in pteridophytes is preliminary, unlike angiosperms. The roots grow laterally to form a dense mat and provide a considerable amount of required support. Hence, removal of the biomass laden with heavy metals becomes effortless. Translocated metals to the aerial parts can be easily separated from the root and disposed. Thus, phytoremediation using ferns is an excellent approach to replace conventional techniques. There is still need for better understanding of mechanism, recovery of metals from the biomass and replacement of traditional disposal method with more efficient and safer method.

\section{REFERENCES}

[1] Antunes APM, Watkins GM, Duncan JR (2000) Batch studies on the removal of gold(III) from aqueous solution by Azolla filiculoides. Biotechnol Lett 23(2001):249-251.

[2] Asbchin SA, Omran AN, Jafari N (2012) Potential of Azolla filiculoides in the removal of $\mathrm{Ni}$ and $\mathrm{Cu}$ from wastewaters. Afr J Biotechnol 11(95):16158-16164.

[3] Baldwin PR, Butcher DJ (2006) Phytoremediation of arsenic by two hyperaccumulators in a hydroponic environment. Microchem. J 85(2007):297- 300.

[4] Begum A, HariKrishna S (2010) Bioaccumulation of trace metals by aquatic plants. Int $\mathbf{J}$ ChemTech Res 2(1):250-254.

[5] Bennicilli R, Stepniewska Z, Banach A, Szajnocha K, Ostrowski J (2003) The ability of Azolla caroliniana to remove heavy metals ( $\mathrm{Hg}(\mathrm{II}), \mathrm{Cr}(\mathrm{III}), \mathrm{Cr}(\mathrm{VI}))$ from municipal waste water. Chemosphere 55(2004):141146.

[6] Bondada BR, Ma LQ (2003) Tolerance of heavy metals invascular plants: Arsenic hyperaccumulation by Chinese Brake fern (Pteris vittata L.). In: Chandra $S$ and Srivastava $M$ (eds) Pteridology in the New Millennium. Kluwer Ackademic Publishers, Dordrecht.

[7] Dhir B (2009) Salvinia: an aquatic fern with potential use in phytoremediation. Environ We Int Sci Tech 4(2009):23- 27.

[8] Dhir B, Sharmila P, Saradhi PP, Sharma S, Kumar R, Mehta D (2011) Heavy metal induced physiological alterations in Salvinia natans. Ecotox Environ Safe 74(2011):1678- 1684.

[9] Drăghiceanu OA, Bobrescu CM, Soare LC (2014) Application of pteridophytes in phytoremediation. Curr Trends Nat Sci 3(6):68-73.

[10] Feng R, Wei C, Tu S, Tang S, Wu F (2010) Simultaneous hyperaccumulation of arsenic and antimony in Cretan Brake fern: Evidence of plant uptake and suncellular distributions. Microchem $\mathbf{J}$ 97(2011):38-43.

[11] Fogarty RV, Dostalek P, Patzak M, Votruba J, Or ET, Tobin JM (1999) Metal removal by immobilized and non- immobilised Azolla filiculoides. Biotechnol Tech 13(1999):533-538.

[12] Fomina M, Gadd GM (2014) Biosorption: current perspectives on concept, definition and application. Bioresource Technol 160(2014): 3-14.

[13] Francesconi K, Visoottiviseth P, Sridokchan W, Goessler W(2001) Arsenic species in an arsenic hyperaccumulating fern, Pityrogramma calomelanos: a potential phytoremediator of arsenic- contaminated soils. The Sci Total Environ 284(2002):27- 35. 
[14] Fuentes II, Espadas-Gil F, Talavera-May C, Fuentes G, Santamaría JM (2014) Capacity of the aquatic fern (Salvinia minima Baker) to accumulate high concentrations of nickel in its tissues, and its effect on plant physiological processes. Aquat Toxicol 155(2014):142- 150.

[15] Ganji MT, Khosravi M, Rakhshaee R (2005) Biosorption of $\mathrm{Pb}, \mathrm{Cd}, \mathrm{Cu}$ and $\mathrm{Zn}$ from the wastewater by treated Azolla filiculoides with $\mathrm{H}_{2} \mathrm{O}_{2}$ / $\mathrm{MgCl}_{2}$. Int J Environ Sci Technol 1(4): 265-271.

[16] García ML, Lodeiro PL, Barriada JL, Herrero R,de Vicente MES (2010) Reduction of Cr(VI) levels in solution using bracken fern biomass: Batch and column studies. Chem Eng J 165(2010):517-523.

[17] Ho YS (2003) Removal of copper ions from aqueous solution by tree fern. Water Res 37(2003):2323-2330.

[18] Ho YS (2004) Effect of $\mathrm{pH}$ on lead removal from water using tree fern as the sorbent. Bioresource Technol 96(2005):1292-1296.

[19] Ho YS, Chiu WT, Hsu CS, Huang CT (2003) Sorption of lead ions from aqueous solution using tree fern as a sorbent. Hydrometallurgy 73(2004):5561.

[20] Ho YS, Wang CC (2003) Pseudo- isotherms for the sorption of cadmium ion onto tree fern. Process Biochem 39(2004):759-763.

[21] Ho YS, Wang CC (2007) Sorption equilibrium of mercury onto ground- up tree fern. J Hazard Mater 156(2008):398-404.

[22] Holtra A, Traczewska TM, Sitarska M, Wojdyla DZ (2010) Assessment of the phytoremediation efficacy of boron- contaminated waters by Savinia natans. Environ Protect Eng 36(4):87- 94.

[23] Jadia CD, Fulekar MH (2008). Phytoremediation of heavy metals: Recent techniques." Afr J Biotechnol 8(6):921-928.

[24] Kanchenko AG, Singh B, Bhatia NP (2007) Heavy metal tolerance in common fern species. Aust J Bot 55(2007):63- 73.

[25] Khosravi M, Rakhshaee R, Ganji MT (2005) Pretreatment process of Azolla filiculoides to removal $\mathrm{Pb}(\mathrm{II}), \mathrm{Cd}(\mathrm{II}), \mathrm{Ni}$ (II) and $\mathrm{Zn}(\mathrm{II})$ from aqueous solution in the batch and fixed- bed reactors. J Hazard Mater B127(2005):228-237.

[26] Ko WH, Ko SS, Chen M (2004) Origin and control of fern weeds in orchid production in greenhouses in Hawaii. Crop Prot 24(5):487-490.

[27] Liu Y, Zhu YG, Chen BD, Christie P, Li, XL (2004) Influence of the arbuscular mycorrhizal fungus Glomus mosseae on the uptake of arsenate by the As hyperaccumulator fern Pteris vittata L. Mycorrhiza 15(2005):187- 192.

[28] Ma LQ, Komar KM, Tu C, Zhang WH, Cai Y, Kennelley ED (2001) A fern that hyperaccumulates arsenic - A hardy, versatile, fast-growing plant helps to remove arsenic from contaminated soils. Nature 409(6820):579.

[29] Malik DJ (1999). Algal biomass as adsorbents for heavy metal sorption from aqueous solutions.
Doctoral dissertation, Loughborough University, England.

[30] Mashkani SG, Ghazvini PTM (2009) Biotechnological potential of Azolla filiculoides for biosorption of $\mathrm{Cs}$ and SR: Application of microPIXE for measurement of biosorption. Bioresource Technol 100(2009):1915-1921.

[31] McGrath SP, Zhao FJ (2003) Phytoextraction of metals and metalloids from contaminated soils. Curr Opin Biotech 14(2003):277- 282.

[32] Natarajan S, Stamps RH, Ma LQ, Saha UK, Hernandez D, Cai Y, Zillioux E (2010) Phytoremediation of arsenic- contaminated groundwater using arsenic hyperaccumulators Pteris vittata L.: Effects of frond harvesting regimes and arsenic levels refill water. J Hazard Mater 185(2011):983-989.

[33] Nishizono H, Ichikawa H, Suziki S, Ishii F (1987) The role of the root cell wall in the heavy metal tolerance in Athyrium yokoscence. Plant and Soil 101(1):15- 20.

[34] Preetha SS, Kaladevi V (2014) Phytoremediation of heavy metals using aquatic macrophytes. World J Environ Sci 3(1):34- 41.

[35] Rahshaee R, Khosravi M, Ganji MT (2005) Kinetic modeling and thermodynamic study to remove $\mathrm{Pb}$ (II), $\mathrm{Cd}(\mathrm{II}), \mathrm{Ni}(\mathrm{II})$, and $\mathrm{Zn}$ (II) from aqueous solution using dead and living Azolla filiculoides. J Hazard Mater B134(2006):120-129.

[36] Ranjitha J, Raj A, Kashyap R, Vijayalakshmi S, Donatus M (2016) Removal of heavy metals from industrial effluent using Salvinia molesta Int J ChemTech Res 9(5):608- 613.

[37] Sajeev S, Ramya PV, Sunitha BC, Hegde S (2013) Phytoremediation of Cadmium using Pteris sp. Prospects in Bioscience: Addressing the issue., Sabu, A. and Augustine, A., eds., Springer, India.

[38] Salido AL, Hasty KL, Lim JM, Butcher DJ (2010) Phytoremediation of arsenic and lead in contaminated soil using Chinese brake ferns (Pteris vittata) and Indian mustard (Brassica juncea). Int $\mathrm{J}$ Phytorem 5(2):89- 103 .

[39] Sharma A, Sachdeva S (2015) Cadmium toxicity and its phytoremediation A review. Int J Sci Eng Res 6(9):395- 405.

[40] Sheel R, Anand M, Nisha K (2015) Phytoremediation of heavy metals $(\mathrm{Zn}$ and $\mathrm{Pb})$ and its toxicity on Azolla filiculoides. Int J Sci Res 4(7):1238- 1241.

[41] Shoel NC, Barkay Z, Ilzycer D, Gilath I, Tel-or E (2001). Biofiltration of toxic elements by Azolla biomass. Water air soil Poll 135(2002):93-104.

[42] Sood A, Uniyal PL, Prasanna R, Ahluwalia AS (2011) Phytoremediation potential of aquatic macrophyte, Azolla. AMBIO 41(2012):122- 137.

[43] Srivastava M, Ma LQ, Singh N, Sigh S (2005). Antioxidant responses of hyper- accumulator and sensitive fern species to arsenic. J Exp Bot 56(415):1335-1342. 
[44] Sukumaran D (2013) Phytoremediation of heavy metals from industrial effluent using constructed wetland technology. Appl Ecol Environ Sci 1(5):9297.

[45] Tangahu BV, Abdullah SRS, Basri H, Idris M, Anuar N, Mukhlisin, M (2011) A review on heavy metals (As, $\mathrm{Pb}$, and $\mathrm{Hg}$ ) uptake by plants through Phytoremediation. Int. J. Chem. Eng 2011:1-31.

[46] Tomko J, Bačkor M, Štofko M (2006) Biosorption of heavy metals by dry fungi biomass. Acta Metall. Slovaca 12(2006):447-451.

[47] Vijayaraghavan K, Yun YS (2008) Bacterial biosorbents and biosorption. Biotecnol Adv 26(3):266- 291.

[48] Yang X, Feng Y, He Z, Stoffella PJ (2005) Molecular mechanisms of heavy metal hyperaccumulation and phytoremediation. J Trace Elem Med Bio 18(2005):339- 353.

[49] Zhao FJ, Dunham SJ, McGrath SP (2002). Arsenic hyperaccumulation by different fern species. New Phytologist 156(1):27-31.

[50] Zhao M, Duncan JR, Hille RPV (1999) Removal and recovery of Zinc from solution and electroplating effluent using Azolla filiculoides. Water Res 33(6):1516-1522.

[51] Zhao M, Duncun JR (1997) Removal and recovery of nickel from aqueous solution and electroplating rinse effluent using Azolla filiculoides. Process Biochem 33(3):249-255. 